\title{
Heleomyzidae (Diptera) in the caves of Poland. Historical overview and new data
}

\author{
Joanna Kocot-Zalewska ${ }^{\ddagger}$, Andrzej J. Woźnica§ \\ $\ddagger$ The Upper Silesian Museum. Department of Natural History, Bytom, Poland \\ $\S$ Wrocław University of Environmental \& Life Sciences, Wrocław, Poland
}

Corresponding author: Joanna Kocot-Zalewska (joannakocotzalewska@gmail.com)

Received: 29 Mar 2020 | Published: 31 Mar 2020

Citation: Kocot-Zalewska J, Woźnica AJ (2020) Heleomyzidae (Diptera) in the caves of Poland. Historical overview and new data. ARPHA Conference Abstracts 3: e52665. https://doi.org/10.3897/aca.3.e52665

\begin{abstract}
The research on invertebrates in caves of Poland dates back to the early 20th century (Kocot-Zalewska and Domagała 2020), but there was never a focus on heleomyzid flies (Diptera: Heleomyzidae). The main purpose of this presentation is to compare historical and new data on heleomyzid flies from the Polish caves with remarks on ecological aspects.
\end{abstract}

The first piece of information about heleomyzid flies was given from the caves and mines in the Sudety Mts (Arndt 1921, Arndt 1923). Among four species of the Heleomyzidae family described from this area, one is noteworthy, it's Oecothea praecox (Loew, 1862) - species considered to be a troglobite (Košel and Woźnica 2019). Unfortunately, there is no specimen in the museum collection as well as no specimen was caught in Polish caves after the Second World War, hence its presence in Polish fauna is questionable (Košel and Woźnica 2019). More information about heleomyzid flies from this area provided Pax and Maschke (1935) and Haduk and Ogorzałek (1970). The next piece on information was given from Tatra Mts (Kowalski 1955, Sobiepanek 1985) and Kraków - Częstochowa Upland (Skalski 1973, Skalski 1981, Papp and Woźnica 1993, Woźnica 2004, Woźnica 2006, Woźnica and Klasa 2009). So far, in the caves of Poland, altogether 17 species were collected, nowadays the list includes 23 species.

The new research was conducted on Częstochowa Upland in the years 2014-2017. The six caves were investigated every month. The material of heleomyzid flies is part of the 
collection from the implementation of the larger project. A total of 179 specimens were collected. Among 16 identified species, 9 were considered as eutroglophiles, 5 species as subtroglophiles and two as trogloxenes.

A comparative analysis based on the applied similarities, using on Ward's minimum variance method, in the Heleomyzid fauna of caves from the mountain and other areas showed significant similarities in the species composition in the Tatra and the Sudety mountains and an important difference between the caves in the mountains and KrakówCzęstochowa Upland.

\section{Keywords}

heleomyzid flies, Częstochowa Upland, Poland, troglophiles, Sudety Mts, Tatra Mts, Kraków-Częstochowa Upland

\section{Presenting author}

Joanna Kocot-Zalewska

\section{Presented at}

The 25th International Conference on Subterranean Biology

\section{Conflicts of interest}

None

\section{References}

- $\quad$ Arndt W (1921) Beitrag zur Kenntnis der Höhlenfauna. Ergebnis einer faunistischen Untersuchung der Höhlen Schlesiens. Zoologischer Anzeiger 52 (12-13): 310-315. [In German].

- $\quad$ Arndt W (1923) Speläobiologische Untersuchungen in Schlesien. Speläologische Jahrbuch 4: 95-114. [In German].

- Haduk Z, Ogorzałek A (1970) Wyniki badań faunistycznych Jaskini Niedźwiedziej. Acta Universitatis Wratislaviensis 127 (Studia geograficzne XIV): 79-84. [In Polish].

- Kocot-Zalewska J, Domagała P (2020) Terrestrial invertebrate fauna of Polish caves - a summary of 100 years of research. Subterranean Biology 33: 45-69. https://doi.org/ 10.3897/subtbiol.33.48805

- Košel V, Woźnica A (2019) First Record Of Oecothea Praecox (Loew, 1862) (Diptera, Heleomyzidae) From Slovakia. Dipteron Bulletin Of The Dipterological Section Of The Polish Entomological Society 35: 72-79. 
- $\quad$ Kowalski K (1955) Fauna jaskiń Tatr Polskich. Ochrona Przyrody 23: 283-333. [In Polish].

- Papp L, Woźnica A (1993) A Revision Of The Palearctic Species Of Gymnomus Loew (Diptera: Heleomyzidae). Acta Zool. Hung 39: 175-210.

- Pax F, Maschke K (1935) Höhlenfauna des Glatzer Schneeberges. Die rezente Metazoenfauna. Beiträge zur Biologie des Glatzer Schneeberges 1: 4-72. [In German].

- Skalski AW (1973) Materiały do znajomości bezkręgowców jaskiń Wyżyny KrakowskoCzęstochowskiej. Rocznik Muzeum Częstochowskiego 3: 161-200. [In Polish].

- $\quad$ Skalski AW (1981) Charakterystyka fauny podziemnej Wyżyny KrakowskoCzęstochowskiej. Rocznik Muzeum Okręgowego w Częstochowie 5 (Przyroda 2): 51-60. [In Polish].

- Sobiepanek E (1985) Fauna jaskiń tatrzańskich. Materiały XV Sympozjum Speleologicznego., 15. Sympozjum Speleologiczne, Ojców, 1985. 71-73 pp.

- Woźnica AJ (2004) Redescription of Scoliocentra (Leriola) brachypterna (Loew, 1873) (Diptera: Heleomyzidae) with description of a new species from Europe. Polskie Pismo Entomologiczne 73: 327-338.

- Woźnica AJ (2006) Gymnomus Caucasicus A New Species Of Heleomyzid Flies From Caucasus Mountains (Diptera: Heleomyzidae). Genus 17 (3): 399-408.

- Woźnica AJ, Klasa A (2009) Heleomyzid Flies Of The Ojców National Park, With Notes On Suillia Lineitergum (Pandelle, 1901) - A Species New To The Fauna Of Poland (Diptera: Heleomyzidae). Fragmenta Faunistica 52 (2): 181-19. https://doi.org/ 10.3161/00159301FF2009.52.2.181 